Kyrychok Inna, $\mathrm{PhD}$ (Pedagogics), Associate Professor, Nizhyn Mykola Gogol State University, Grafska Str., 2, Nizhyn, Chernihivska Oblast, Ukraine 16600 ORCID: 0000-0002-8376-9688 Researcher ID: 5842-2019 Tonkonoh Irina, Senior lecturer, $\mathrm{PhD}$ (Pedagogics), Kyiv National University of Trade and Economics, 19, Kyoto str., Kyiv, 02156, Ukraine ORCID: 0000-0001-8488-8526

Researcher ID: O-4246-2016

Mehela Kateryna, $\mathrm{PhD}$ (Pedagogics), Assistant, Taras Shevchenko National University of Kyiv, 60 Volodymyrska Street, City of Kyiv, Ukraine, 01033

ORCID: 0000-0002-5362-3194

\title{
ASSESSMENT OF THE SCOPE OF RHETORIC COMPETENCE POSSESSED BY PROSPECTIVE PRIMARY SCHOOL TEACHERS
}

The article outlines the results of the verification experiment aimed at determining the level of rhetoric competence of the masters trained at Mykola Hohol State University of Nizhyn and primary school teachers in Chernihiv region. The article highlights the conclusions of empirical analysis dealing with the students and teachers' rhetoric, linguistic and communicative awareness, rhetoric competency levels, genre-based thinking strategies, speaking competencies, engagement in rhetoric performance, motivation for rhetoric-based self-improvement, reflection competencies relevant to rhetoric and pedagogical activity and self-evaluation skills regarding communicative abilities.

Keywords: rhetoric competence, prospective primary school teachers, communication, pedagogical activity.

Киричок Інна, Тонконог Ірина, Мегела Катерина. Діагностика сформованості риторичної компетентності майбутніх вчителів початкових класів.

Стаття узагальнює результати проведеного констатувального експерименту, щуо мав на меті визначити рівень риторичної компетентності магістрів 
Ніжинського університету імені Миколи Гоголя та учителів початкових шкіл Чернігівської області. У статті представлено результати емпіричного аналізу риторичної, мовознавчої та комунікативної обізнаності, сформованості риторичних умінь, рівня розвитку жанрового мислення, мовленнєвих умінь; позитивноактивного ставлення до риторичної діяльності, позитивної мотивованості до риторичного самовдосконалення, рефлексивних умінь щодо здатності виконувати риторико-педагогічну діяльність, самооиінки комунікативних здібностей майбутніх учителів та класоводів шкіл.

Ключові слова: риторична компетентність, майбутні вчителі початкових класів, спілкування, педагогічна діяльність.

Relevance of research topic. Remarkable changes occurring in social, economic and cultural spheres at the beginning of the 21st century in Ukraine requires the management of higher education institutions to meet new demands for language education and speech training of future primary school teachers.

Significant acceleration of communication processes influenced by informatization and globalization is considerably intensifying information and business environment. It is not surprising that the teacher's communicative skills (such as an ability to hold a private conversation with pupils and their parents, to speak to a large audience of colleagues and in mass media) are currently gaining a particular importance.

The choice of the research topic is accounted, on the one hand, for the objective necessity to address the problem of forming rhetoric competence of prospective teachers enrolled in the master's training programme, and, on the other hand, for the lack of research to consider this issue integrally.

Formulation of the Problem. An ability to speak confidently and persuasively in front of other people is a compulsory skill for every public person, especially a teacher who wants to succeed in the professional activity.

Consequently, the value of rhetoric competence of the future primary school teacher is increasing, since the teacher's efficient professional performance is subject to mastering comprehensive rhetoric knowledge and skills as well as accomplishing a competent pedagogically-oriented resolution of various learning, teaching and educational tasks.

Analysis of the Latest Researches and Publications. The overview of current scientific publications by national and foreign experts in rhetoric, rhetoric education and communicative competence reveals the fact of insufficient coverage of the issue of rhetoric competence development possessed by prospective teachers enrolled in the master's training programme. The works by Annushkin V. (2015), Vishneva L. (2015), Ladyizhenskaya T. (2018), Martyinenko S., Belkina Yu. (2015), Simakova E., Han O. (2015), Tukmacheva L., Nischeta V., Gorobets L., Golub N. and others have provided significant insights for our study, in particular, their findings enabled us to 
determine the criteria and scale indicators of the rhetoric competence of the future primary school teachers.

Presenting main material. Rhetoric competence of prospective primary school teachers is regarded as a complex integral unit, a basic component of professional and pedagogical competence, which involves comprehensive rhetoric, speech and language knowledge (cognitive component), a matrix of professionally-bound rhetoric competencies and skills, the language personality's strengths (efficiency and performance component), coupled with the willingness and ability of the graduate student to successfully carry out rhetoric and pedagogical activity and perform followup self-assessment (reflective and motivational component).

In order to test the underpinning conceptual ideas a verification experiment has been conducted at Mykola Hohol State University of Nizhyn. The sample group comprised 45 masters majoring in the programme 013 «Primary Education» and 45 primary school teachers of Nizhynand Chernihiv region, who completed the course in 2017-2018.

In view of the subject matter of rhetoric competence possessed by prospective teachers, and specified criteria of the cognitive, efficiency, performance, reflective and motivational components, three development scales have been identified: unconscious incompetence, conscious incompetence and unconscious competence level.

The unconscious competence development level is described in terms of a high degree of motivation and willingness to perform a top-grade rhetoric activity, a rewarding motivation for rhetoric-based self-improvement; developed self-reflection and self-evaluation skills; profound knowledge of the principles of effective communication, peculiarities of communication in the area of linguistic performance, rules of cooperative communication, linguistic and rhetoric concepts and notions. The individual creatively uses professional rhetoric competencies and skills in all situations of business communication, manages genre-based thinking strategies and possesses well-developed speaking competencies.

At the conscious incompetence development level individuals have a situational motivation relative to rhetoric-based self-improvement, low-developed self-assessment skills regarding communicative abilities. The individual has basic knowledge of the principles of effective communication, peculiarities of communication in the area of linguistic performance, rules of cooperative communication, linguistic and rhetoric concepts and notions. The individual faces difficulties to carry out rhetoric analysis of a particular pedagogical communication situation and to use appropriate speech means and rhetorical techniques. The genre-based thinking strategies are poor.

The unconscious incompetence development level is marked by ignoring the value to acquire rhetoric competence. The cognitive interest is occasional and feeble. The individuals lack motivation for rhetoric-based self-improvement. They possess low level of self-assessment skills regarding communicative abilities. The individuals have elementary and fragmentary knowledge of the principles of effective 
communication, peculiarities of communication in the area of linguistic performance, rules of cooperative communication, linguistic and rhetoric concepts and notions. They are unable to perform rhetoric analysis of a particular pedagogical communication situation and to use relevant speech means and rhetoric techniques. The genre-based thinking strategies are unsatisfactory.

On account of the subject matter of the cognitive component, its criterion is appropriately referred to as perceptive and informational. In order to identify the indicators of this component a uniquely designed test «Awareness scale in areas of rhetoric, communication and linguistics» has been used.

The consolidated results obtained by this indicator are displayed in Table 1 . (See Table 1).

Table 1

\section{Distribution of rhetoric competence levels based on cognitive component}

\begin{tabular}{|l|c|c|c|c|c|c|}
\hline \multirow{2}{*}{\multicolumn{1}{|c|}{ Indicators }} & \multicolumn{5}{|c|}{ Levels in \% } \\
\cline { 2 - 7 } & \multicolumn{2}{|c|}{$\begin{array}{c}\text { Unconscious } \\
\text { competence }\end{array}$} & \multicolumn{2}{c|}{$\begin{array}{c}\text { Conscious } \\
\text { incompetence }\end{array}$} & \multicolumn{2}{|c|}{$\begin{array}{c}\text { Unconscious } \\
\text { incompetence }\end{array}$} \\
\cline { 2 - 7 } & Masters & Teachers & Masters & Teachers & Masters & Teachers \\
\hline $\begin{array}{l}\text { Awareness of the } \\
\text { principles of effective } \\
\text { communication; } \\
\text { peculiarities of } \\
\text { communication in the } \\
\text { area of linguistic } \\
\text { performance; rules } \\
\text { of cooperative } \\
\text { communication; key } \\
\text { linguistic and rhetoric } \\
\text { concepts and notions }\end{array}$ & 11.5 & 11 & 45 & 47 & 43.5 & 42 \\
\hline
\end{tabular}

As shown in Table 1, the indicators of the rhetoric competence development relative to the cognitive component of informational and perceptive criterion at the verification stage of the experiment have referred mostly to the conscious incompetence level, with approximately equal quantitative indicators manifested by the prospective teachers and primary school teachers: $11.5 \%$ of the surveyed masters and $11 \%$ of the teachers have reported the unconscious competence level; $45 \%$ of the students and $47 \%$ of the class teachers have demonstrated the conscious incompetence level, $43.5 \%$ of the masters and $42 \%$ of the teachers have recorded an unconscious incompetence level.

The scope of the rhetoric competence possessed by the prospective primary school teachers in terms of the efficiency and performance component has been 
determined by inspecting the distinguished indicators of activity and behavior-based criterion.

A uniquely designed test «The scope of rhetoric skills» has been applied in order to identify the development level of rhetoric skills possessed by the prospective teachers. A questionnaire «Features of the teacher's genre thinking» has been used to investigate the development level of the teachers' genre-based thinking strategies. The scales of speech skills have been examined by observation and peer review methods.

The consolidated results obtained by this indicator are displayed in Table 2 (See Table 2).

Table 2

\section{Distribution of rhetoric competence levels based on efficiency and performance component}

\begin{tabular}{|l|c|c|c|c|c|c|}
\hline \multirow{2}{*}{\multicolumn{1}{|c|}{ Indicators }} & \multicolumn{6}{c|}{ Levels in \% } \\
\cline { 2 - 7 } & \multicolumn{2}{|c|}{$\begin{array}{c}\text { Unconscious } \\
\text { competence }\end{array}$} & \multicolumn{2}{c|}{$\begin{array}{c}\text { Conscious } \\
\text { incompetence }\end{array}$} & \multicolumn{2}{c|}{$\begin{array}{c}\text { Unconscious } \\
\text { incompetence }\end{array}$} \\
\cline { 2 - 7 } & Masters & Teachers & Masters & Teachers & Masters & Teachers \\
\hline $\begin{array}{l}\text { Rhetoric } \\
\text { competencies }\end{array}$ & 9 & 10 & 43 & 45 & 48 & 45 \\
\hline $\begin{array}{l}\text { Genre-based thinking } \\
\text { strategies }\end{array}$ & 10 & 11 & 42 & 43 & 48 & 46 \\
\hline $\begin{array}{l}\text { Speaking } \\
\text { competencies }\end{array}$ & 20 & 21 & 51 & 53 & 29 & 26 \\
\hline Total & $\mathbf{1 3}$ & $\mathbf{1 4}$ & $\mathbf{4 5 . 3}$ & $\mathbf{4 7}$ & $\mathbf{4 1 . 6}$ & $\mathbf{3 9}$ \\
\hline
\end{tabular}

As shown in table 2, the indicators of the rhetoric competence development possessed by the prospective primary school teachers in terms of the efficiency and performance component of the activity and behavior-based criterion at the verification stage of the experiment has referred mostly to the conscious incompetence level, with approximately equal quantitative indicators manifested by the prospective teachers and primary school teachers: $13 \%$ of the surveyed masters and $14 \%$ of the teachers have reported the unconscious competence level; $45.3 \%$ of the students and $47 \%$ of the class teachers have demonstrated the conscious incompetence level, $41.6 \%$ of the masters and $39 \%$ of the teachers have recorded the unconscious incompetence level.

The scales of rhetoric competence development possessed by the prospective primary school teachers relative to the reflective and motivational component have been determined by inspecting the specified indicators of the subject-oriented criterion.

The indicators of the specified criterion have been identified by the following diagnostic tools: a uniquely designed questionnaire «My attitude to rhetoric activity» 
has been used to verify a rewarding motivation for rhetoric-based self-improvement. A test involving the methodology proposed by V. Sinyavsky, B. Fedoryshyn has been employed to check self-reflection and self-evaluation skills regarding communicative abilities. A questionnaire «What type of speaker are you?» (Annushkin, p. 46) has been used to test reflection competency to perform rhetoric and pedagogical activity.

The consolidated results obtained by this indicator are displayed in Table 3 (See Table 3).

Table 3

\section{Distribution of rhetoric competence levels based on reflective and motivational component}

\begin{tabular}{|c|c|c|c|c|c|c|}
\hline \multirow{3}{*}{ Indicators } & \multicolumn{6}{|c|}{ Levels in \% } \\
\hline & \multicolumn{2}{|c|}{$\begin{array}{l}\text { Unconscious } \\
\text { competence }\end{array}$} & \multicolumn{2}{|c|}{$\begin{array}{c}\text { Conscious } \\
\text { incompetence }\end{array}$} & \multicolumn{2}{|c|}{$\begin{array}{l}\text { Unconscious } \\
\text { incompetence }\end{array}$} \\
\hline & Masters & Teachers & Masters & Teachers & Masters & Teachers \\
\hline $\begin{array}{l}\text { Reflection } \\
\text { competencies to } \\
\text { perform rhetoric } \\
\text { and pedagogical } \\
\text { activity }\end{array}$ & 21 & 22 & 52 & 54 & 27 & 24 \\
\hline $\begin{array}{l}\text { Self-assessment } \\
\text { skills regarding } \\
\text { communicative } \\
\text { abilities }\end{array}$ & 26 & 24 & 56 & 54 & 18 & 22 \\
\hline $\begin{array}{l}\text { Willingness, } \\
\text { rewarding } \\
\text { motivation for } \\
\text { rhetoric-based self- } \\
\text { improvement }\end{array}$ & 25 & 28 & 55 & 58 & 20 & 14 \\
\hline Total & 24 & 24.6 & 54.3 & 55.3 & 21.6 & 20 \\
\hline
\end{tabular}

As shown in table 3, the indicators of the rhetoric competence development possessed by the prospective primary school teachers regarding the reflective and motivational component of the subject-oriented criterion at the verification stage of the experiment have referred mostly to the conscious incompetence and unconscious incompetence level, with approximately equal quantitative indicators manifested by the prospective teachers and primary school teachers: $24 \%$ of the surveyed masters and $24.6 \%$ of the teachers have reported the unconscious competence level; $54.3 \%$ of the students and $55.3 \%$ of the class teachers have demonstrated the conscious incompetence level, $21.6 \%$ of the masters and $20 \%$ of the teachers have recorded the unconscious incompetence level. 
The consolidated results on the scope of rhetoric competence possessed by the prospective primary school teachers at the verification stage of the experiment are shown in Table 4 (See Table 4).

Table 4

\section{Distribution of the scope of the rhetoric competence}

\begin{tabular}{|l|c|c|c|c|c|c|}
\hline \multirow{2}{*}{ Indicators } & \multicolumn{5}{|c|}{ Levels \% } \\
\cline { 2 - 7 } & \multicolumn{2}{|c|}{$\begin{array}{c}\text { Unconscious } \\
\text { competence }\end{array}$} & \multicolumn{2}{c|}{$\begin{array}{c}\text { Conscious } \\
\text { incompetence }\end{array}$} & \multicolumn{2}{|c|}{$\begin{array}{c}\text { Unconscious } \\
\text { incompetence }\end{array}$} \\
\cline { 2 - 7 } & Masters & $\begin{array}{c}\text { Class } \\
\text { teachers }\end{array}$ & Masters & $\begin{array}{c}\text { Class } \\
\text { teachers }\end{array}$ & Masters & $\begin{array}{c}\text { Class } \\
\text { teachers }\end{array}$ \\
\hline $\begin{array}{l}\text { Cognitive } \\
\text { component }\end{array}$ & 11 & 11.5 & 45 & 47 & 43.5 & 42 \\
\hline $\begin{array}{l}\text { Efficiency and } \\
\text { performance } \\
\text { component }\end{array}$ & 13 & 14 & 45.3 & 47 & 41.6 & 39 \\
\hline $\begin{array}{l}\text { Reflective and } \\
\text { motivational } \\
\text { component }\end{array}$ & 24 & 24.6 & 54.3 & 55.3 & 21.6 & 20 \\
\hline Total & $\mathbf{1 6}$ & $\mathbf{1 6 . 7}$ & $\mathbf{4 8 . 2}$ & $\mathbf{4 9 . 7}$ & $\mathbf{3 5 . 5}$ & $\mathbf{3 3 . 6}$ \\
\hline
\end{tabular}

According to the figures presented in Table 4, the quantitative data manifested by the prospective teachers and class teachers slightly differ and fluctuate around $2 \%$; the respondents have mostly referred to the reflective and motivational component of rhetoric competence, since the highest indicators shown by the prospective teachers with the rhetoric unconscious competence at the verification stage of the experiment have been respectively represented by $24 \%$ of the masters and $24.6 \%$ of the class teachers, the least formed referred to the cognitive component; the unconscious competence level has been recorded by $11 \%$ of the masters and $11.5 \%$ the class teachers respectively.

The study of the components of the acquired rhetoric competence at the verification stage of the experiment has enabled us to determine that the masters' scope of competence refers mostly to the conscious incompetence level of the rhetoric competence, manifested by $48.2 \%$ of the prospective teachers and $49.7 \%$ of the teachers. $16 \%$ of the masters and $16.7 \%$ of the teachers have showed the unconscious competence level; the unconscious incompetence level has been recorded by $35.5 \%$ of the prospective teachers and $33.6 \%$ of the class teachers.

Conclusion. The most essential prerequisite for the development of rhetoric competence is the acquisition of rhetorical knowledge, rhetoric competencies and particular personal strengths (advanced genre-based thinking strategies, enriched and developed cohesive speech), willingness and ability of the graduate student to 
successfully carry out rhetoric and pedagogical activity and perform follow-up selfassessment, embraced by reflection efforts and managed by the teacher of the higher education institution.

The results of the experiment have highlighted actual poor development of the cognitive, efficiency and performance components of the rhetoric competence possessed by the prospective teachers, as it occurred that only one fifth of the respondents have manifested the unconscious competence level of rhetoric competence. The requirement for the development of the cognitive, efficiency and performance components of rhetoric competence is crucial in the higher educational process. It is assumed that the course «Pedagogical Rhetoric» introduced into the training program of prospective primary school teachers shall ensure comprehensive formation of rhetoric competence of future teachers.

Further research prospects are regarded in designing the pedagogical tool box intent to develop rhetoric competence of prospective teachers.

\section{REFERENCES}

1. Annushkin, V. (2015). Filologiya - slovesnost - ritorika: novyie zadachi klassicheskih ucheniy. Ritorika v kontekste obrazovaniya i kulturyi: materialyi XIX Mezhdunarodno ynauchnoy konferentsii, 9-15.

2. Belkina, Yu. (2015). Formirovanie professionalnoy ritoricheskoy kompetentsii studentov v kurse «Pedagogicheskaya ritorika». Samarskiy nauchnyiy vestnik, (1(10)), $38-41$.

3. Han, O. (2015). Formirovanie ritoricheskoy kompetentsii studentov tehnicheskogo vuza $\mathrm{v}$ protsesse izucheniya yazyikovyih distsiplin. Retrieved from : http://web.snauka.ru/issues/2015/11/59421

4. Ladyizhenskaya, T. (2015). Perspektivy i dalneyshego razvitiya ritoriki. Ritorika $v$ kontekste obrazovaniya $i$ kulturyi: materialyi XIX Mezhdunarodnoy nauchnoy konferentsii, 58-62.

5. Vishneva, L. (2018). Formirovanie rechevoy kompetentsii buduschih spetsialistov $\mathrm{v}$ oblasti prava. Retrieved from : http://dom-hors.ru/rus/files/arhiv zhurnala/spp/2018/6/pedagogics/vishneva.pdf 